\title{
Analisis Pengelolaan Keuangan pada UMKM di Kota Batam
}

\author{
Khadijah $^{1}$, Neni Marlina BR Purba ${ }^{2 *}$ \\ ${ }^{1,2)}$ Universitas Putera Batam \\ khadijah@puterabatam.ac.id, neni.Marlina@puterabatam.ac.id
}

*Corresponding Author

Submitted: November 13, 2020

Accepted: December 21, 2020

Published: February 1, 2021

\begin{abstract}
MSMEs are the main pillars of the Indonesian economy. One of the obstacles faced by MSMEs today is the number of MSMEs opening businesses with the same type of products. The purpose of this research is to be able to analyze financial management in MSMEs in Batam City. So that it can develop and be consistent with the effort. The method used is a qualitative descriptive method with a sample of 5 MSMEs namely Toko Pakaian Cantik, Toko Gamis Taqeeya, Toko Ringan, Toko Fashion Muslim, Toko Fathia Collection are in the type of trading industry with criteria still active and willing to conduct interviews on their business. The results of the study in accordance with 4 indicators in financial management showed that from the overall MSMEs studied using planning in the use of budgets, making simple recordings and using sufficient control. However, not all MSMEs understand the reporting indicators in business financial statements.
\end{abstract}

Keywords: MSMEs; Financial Management; MSME Performance

\section{PENDAHULUAN}

UMKM merupakan penopang bagi perekonomian yang ada di suatu negara. UMKM diharapkan dapat meningkatkan ekonomi usaha secara keseluruhan dengan berbagai peluang usaha dari krisis perekonomian. Tantangan yang paling sering ditemui oleh pelaku usaha adalah pengelolaan keuangan. Hal yang selalu disangkut pautkan dengan pengendalian dana adalah akuntansi. Bagi sebagian pelaku usaha akuntansi merupakan hal yang sulit untuk diaplikasikan karena tidak memiliki bidang ahli dalam hal tersebut. Sehingga banyak dari pelaku usaha menganggap pengelolaan keuangan merupakan hal yang tidak penting.

Data perekonomian Indonesia yang dirilis oleh Kementrian Koperasi dan UKM menyebutkan bahwa hingga tahun 2018 jumlah UMKM di Indonesia sebanyak 64.194.057 unit usaha atau 99,99\% dari total seluruh sektor usaha yang memperkerjakan $97,00 \%$ tenaga kerja yang ada (Depkop, 2018). Dengan melihat angka-angka di atas tentunya sektor UMKM memiliki peran yang sangat penting dalam pembangunan perekonomian di Indonesia. Data yang diperoleh dari Dinas Usaha Mikro Kota Batam bahwa ada 1.499 UMKM di tahun 2019-2020 dengan persentase 0,19\% untuk Batam Kota dan ada 0,039 untuk jenis industri perdagangan di Kota Batam (Batam, 2019). Perkembangan untuk industri perdagangan cukup signifikan untuk daerah Batam Kota tetapi pengelolaan keuangan tidak banyak yang menerapkan dikarenakan banyak dari pelaku usaha memilih untuk tidak menggunakannya untuk jangka panjang.

Perkembangan UMKM saat ini sangat pesat dan selalu update. Sehingga membuat pelaku usaha harus bekerja ektra untuk dapat mengundang pelanggan agar dapat bersaing dengan pelaku usaha lainnya. Banyaknya usaha yang berkembang di Kota batam dapat terlihat dengan banyaknya daftar UMKM yang terdaftar di Dinas Usaha Mikro dan Kecil kota Batam setiap tahunnya. Sehingga pelaku usaha dituntut untuk kreatif dalam mengembangkan usahanya. Usaha yang berkembang dan dapat konsisten juga harus diimbangi dengan mengatur keuangan yang baik. Hal yang ditemukan banyaknya persoalan yang terjadi pada UMKM di Kota Batam bahwa banyak dari pelaku usaha tidak mengelola keuangan dengan baik dikarenakan kurangnya keahlian dalam perencanaan, pelaksanaan, pengendalian serta pelaporan keuangan pada usaha. Padahal kota batam merupakan kota sangat berkembang dalam hal bisnis dan banyaknya usaha yang berkembang disetiap tempat 
namun bukan berarti tidak ditemukan masalah mengenai pengelolaan keuangan dalam usaha. Masih sangat banyak pelaku usaha yang tidak mengerti dan mengabaikan adanya pengelolaan keuangan. Untuk dapat konsisten dengan membuat perencanaan dan pengelolaan keuangan sangatlah sulit. Hal ini dikarenakan pengelolaan keuangan lebih kepada perusahaan dan juga usaha yang bersifat tetap. Sehingga lebih mudah bagi pelaku usaha untuk dapat menerapkannya. Selanjutnya, akibat buruknya pengelolaan dana diperusahaan tidak dapat mencegah, mendeteksi maupun mengekoreksi tindak kecurangan yang terjadi diperusahaan.

Pelaku usaha memiliki perilaku yang berbeda dalam pengelolaan keuangan dengan usaha yang miliki dibandingkan dengan usaha yang sudah bekembang sesuai dengna pernyataan oleh (Davayudhanti et al., 2019). Terabaikannya pengelolaan keuangan berakibat dari mungkin tidak terlihat secara jelas, tanpa adanya metode akuntansi yang effektif pada usaha dapat menjadi bangkrut. Informasi mengenai keuangan usaha harus bersifat terbuka agar dapat menjadi daya tarik bagi penggunanya. Sangat banyak dari pelaku UMKM yang merasa bahwa usaha yang mereka jalankan sudah berjalan dengan normal, namun tidak memiliki perkembangan (Risnaningsih, 2017). Hal ini bisa saja menjadi suatu pertanyaan bagaimana dengan laba yang didapatkan setiap periode, aset tidak berwujud hingga aset berwujud yang dimiliki pada UMKM. Banyak hal yang menarik terkait UMKM. Salah satunya adalah perilaku dari pelaku usaha (Kostini \& Raharja, 2020). UMKM sering kali mendapatkan masalah dalam modal, kekurangan pelanggan, kekurangan pengetahuan dan kekurangan kewirausahaan sehingga semua hal ini dapat menjadi suatu ancaman bagi UMKM (Tanan \& Dhamayanti, 2020).

Tahapan yang paling mudah dan sederhana dalam mengelola keuangan pada UMKM dengan cara mengalikasikan akuntansi. Akuntansi dapat menjadikan usaha dalam memperoleh informasi yang baik agi usaha. Sepanjang UMKM dapat menggunakan uang sebagai alat transaksi, akuntansi akan terus dibutuhkan oleh UMKM. Informasi yang diperoleh oleh UMKM berupa informasi kinerja perusahaan, perhitungan pajak, posisi dana perusahaan, perubahan modal, pemasukan dan pengeluaran kas (Noer Sasongko, 2019). Banyak dari pelaku usaha yang merasa sulit untuk menerapkan akuntansi dalam usaha dikarenakan tidak ada buku pegangan yang dapat menjawab dari pertanyaan tentang akuntansi (Fatwitawati, 2018).

Persoalan yang muncul di lapangan bahwa UMKM dapat melakukan perencanaan anggaran dengan baik. Namun tidak banyak UMKM yang melakukan pengelolaan keuangan dengan keseluruhan. Dari empat indikator yang ada pada pengelolaan keuangan yaitu penggunaan anggaran, pencatatan, pelaporan dan pengendalian hanya tiga indikator yang digunakan oleh pelaku usaha. Ketidakmampuan dalam pemahaman dalam akuntansi dapat menyebabkan usaha tidak berkembang dengan baik.

Penelitian ini perlu dilakukan karena pengelolaan keuangan sangat dibutuhkan bagi UMKM dan banyak dari pelaku usaha tidak memahami dan mengaplikasikan dari pengelolaan akuntansi dalam usaha yang dijalankan. Sehingga dari hal ini menjadi keberlanjutan dari penelitian lain yang mana objek pada penelitian sangat mudah ditemui dan diberikan pemahaman mengenai pengelolaan keuangan menggunakan empat indikator seperti penggunaan anggaran, pencatatan, peaporan dan pengendalian terhadap kinerja UMKM. Menurut (Suindari \& Juniariani, 2020) kinerja merupakan hasil seseorang dalam melakukan pekerjaan secara keseluruhan dalam waktu tertentu.

Pemerintah memberi perhatian yang sangat besar terhadap perkembangan Usaha Mikro Kecil Dan Menengah (UMKM). UMKM sangat berperan dalam mengurangi tingkat pengangguran. Oleh karena itu, keberhasilan UMKM mampu meningkatkan perekonomian Kegiatan operasional UMKM di Indonesia dapat mandiri dan tidak menanggung beban besar akibat krisis tersebut. Dan yang membuat UMKM lebih tangguh lagi karena tingkat resiko yang dimiliki lebih kecil dalam menyalurkan dan memanfaatkan dana perbankan.

\section{Penelitian Terdahulu}

\section{STUDI LITERATUR}

Usaha Mikro, Kecil, dan Menengah (UMKM) memiliki definisi yang berbeda pada setiap literatur menurut beberapa instansi atau lembaga bahkan undang-undang. Sesuai dengan UndangUndang nomor 20 tahun 2008 tentang Usaha Mikro, Kecil, dan Menengah, UMKM (Sabiq Hilal Al Falih et al., 2019). 
Pada penelitian ini indikator yang dimiliki bersifat kesatuan atau tidak dapat dipisahkan dari manajemen keuangan sehingga faktor pembeda dalam penelitian ini dapat berupa metode yang disesuaikan dengan keadaan yang dihadapi oleh peneliti. Metode kualitataif dengan study kasus pada 5 UMKM dengan jenis industri perdagangan yang ada di Kota Batam. UMKM yang dipilih merupakan pelaku usaha yang bersedia dalam memberikan informasi keuangan usaha dan memiliki kesulitan dalam mengelola keuangan sehingga dapat memberikan solusi untuk mengatur keuangan usaha.

Anggaran sebagai alat pencapai tujuan perusahaan, yaitu dalam rangka dalam memperoleh laba. Variabel ini akan dilihat dari pelaku usaha dalam merencanakan anggaran masa depan, penggunaan anggaran pribadi hingga anggaran usaha. Indikator pencatatan menurut (Diyana, 2017) merupakan kegiatan mencatat transaksi keuangan yang telah terjadi, penulisannya secara kronologis dan sistematis. Pencatatan sendiri digunakan sebagai penanda bahwa telah terjadi transaksi yang terjadi pada periode yang ditentukan dalam organisasi. Penyusunan pencatatan diawali dari pengumpulan dokumen yang mendukung terjadinya transaksi seperti nota, kuitansi, faktur, dll.

Langkah selanjutnya menulis transaksi dalam jurnal, lalu di posting ke dalam buku besar. Jenisjenis catatan adalah jurnal, buku besar, worksheet. Indikator pelaporan merupakan langkah selanjutnya setelah selesai memosting ke buku besar, dan buku besar pembantu. Postingan dalam buku besar dan buku besar pembantu akan ditutup pada akhir bulan, setelah itu akan dipindahkan keikhtisar laporan keuangan sebagai dasar penyusunan laporan keuangan. Jenis-jenis laporan keuangan ada Laporan Arus Kas, Laporan Laba Rugi, Laporan Posisi Keuangan. Penyajian laporan keuangan harus tertib administrasi yang tersusun dari setiap periode. Penyajian laporan keuangan akan sangat mudah diakses oleh UMKM ketika menggunakan teknologi dengan sistem pencatatan yang efektif dan efisien (Ria, 2018). Dan indikator pengendalian merupakan pengukuran hingga mengevaluasi kinerja dari bagian organisasi, jika diperlukan akan dilakukan perbaikan. Untuk menjamin bahwa perusahaan atau organisasi mempu mencapai tujuan yang telah ditetapkan dapat dilakukan pengendalian. Pengendalian awal, pengendalian berjalan, dan pengendalian umpan balik merupakan jenis-jenis pengendalian. Pada model penelitian dibawah ini pengelolaan keuangan memiliki fungsi keuangan yang terdiri atas empat indikator yaitu penggunaan anggaran, pencatatan, pelaporan serta pengendalian dalam keuangan yang akan mempengeruhi dari kinerja keuangan UMKM. Sehingga dari empat indikator tersebut tidak dapat dipisahkankan dan dapat sebagai alat ukur dalam menilai kinerja UMKM. Dalam kinerja UMKM yang baik harus memiliki perencanaan yang terencana, baik itu perencanaan saat ini maupun perencanaan masa depan. Begitu juga dalam pencatatan yang dibuktikan dengan adanya pencatatan transaksi yang terjadi dilakukan pencatatan dan menggunakan pengendalian seperti kwitansi, nota. Selain dari itu pelaku usaha juga harus melakukan pelaporan keuangan dalam bentuk laporan keuangan sehingga dapat menilai usaha yang mereka geluti dengna melihat laporan keuangan.

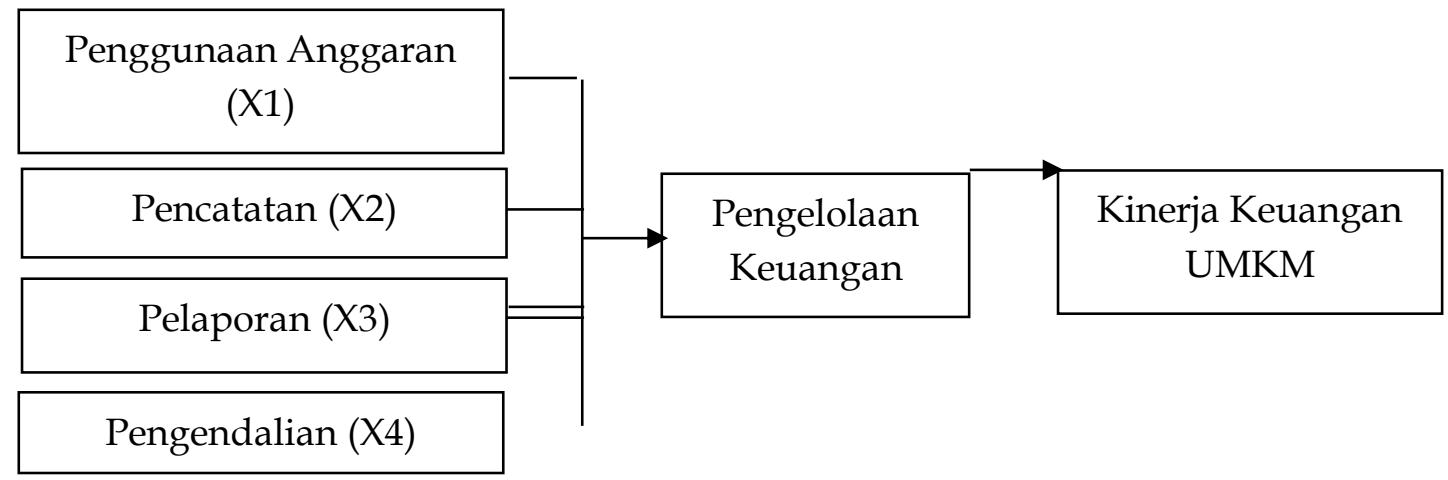

Gambar 1. Model Penelitian

Sumber: Data Penelitian, 2020

METODE

Populasi merupakan keseluruhan jumlah atas obyek atau subyek yang mempunyai karakteristik dan kualitas tertentu yang diterapkan oleh peneliti untuk diteliti dan kemudian ditarik 
kesimpulannya (Sujarweni, 2020). Populasi dalam penelitian ini adalah UMKM yang terdaftar dalam Dinas Koperasi dan Usaha Mikro kota Batam tahun 2017-2020 yang masih aktif dan di industri perdagangan di Kota Batam. Sampel merupakan bagian dari populasi yang akan diteliti. Sampel dalam penelitian kualitatif dinamakan sumber data, informan, dan narasumber yang merupakan sumber informasi. Sampel yang dipilih pada penelitian ini adalah sebanyak 5 UMKM yang bersedia untuk diwawancarai dan diobservasi langsung ke tempat usaha. Wawancara dilakukan dengan menyiapkan beberapa pertanyaan dan memberikan solusi untuk permasalahan yang dihadapi oleh pelaku UMKM terkait dengan adanya pengelolaan keuangan. Pelaksanaan ini dilakukan secara bertahap dengan menggunakan metode acak, dimana peneliti akan mendata setiap pelaku usaha di industri perdagangan yang bersedia untuk diwawancara dan diobservasi mengenai pengelolaan keuangan yang dilakukan oleh UMKM. Metode yang digunakan dalam penelitian ini adalah study kasus yang dilakukan dengan mengumpulkan berbagai informasi dan mendapatkan suatu solusi.

Jenis data yang akan digunakan dalam penelitian ini adalah data kualitatif yang merupakan data yang berupa kata-kata, tidak dalam bentuk angka. Data kualitatif ini diperoleh dengan teknik observasi dan wawancara. Data kualitatif yang dibutuhkan berupa profil perusahaan yang dijadikan objek peneltian dan uraian singkat mengenai pengelolaan keuangan di UMKM kota batam. Data kualitatif yang berbentuk angka atau bilangan berupa pencatatan dan pelaporan UMKM.

Teknik analisis data yang dilaksanakan dalam menganalisa penelitian adalah metode analsis kualitatif deskriptif. Metode ini dilakukan dengan cara dikumpulkan, disusun, diinterpretasikan dan dianalisis sehingga dapat memberikan keterangan yang relevan untuk masalah yang dihadapi oleh UMKM.

Variabel yang digunakan dalam penelitian ini adalah ada 4 variabel dalam pengelolaan keuangan. Dimana 4 variabel ini saling bersangkutan antara satu dengan lainnya. Variabel tersebut adalah penggunaan anggaran, pencatatan, pelaporan, dan pengendalian. UMKM akan dilakukan observasi dan wawancara mengenai keempat indikator ini dalam usaha yang kembangkan.

\section{HASIL}

Usaha mikro yang menjadi penelitian ini adalah UMKM yang berada dalam data Dinas Koperasi dan Usaha Mikro yang berlokasi di Kecamatan Batam Kota dan sekitarnya.

Tabel 1. Data Responden

\begin{tabular}{cllcl}
\hline No & \multicolumn{1}{c}{ Nama Usaha } & \multicolumn{1}{c}{ Alamat } & $\begin{array}{c}\text { Tahun } \\
\text { Berdiri }\end{array}$ & Jenis Usaha \\
\hline $\mathbf{1}$ & Toko Pakaian Cantik & $\begin{array}{l}\text { Dc Mall Lt. Dasar Blok A } \\
\text { No. 50-54 }\end{array}$ & 2014 & Perdagangan \\
\hline $\mathbf{2}$ & Toko Gamis Taqeeya & \multicolumn{1}{c}{ Puri Legenda B.17/11 } & 2011 & Perdagangan \\
\hline $\mathbf{3}$ & $\begin{array}{l}\text { Toko Makanan } \\
\text { Ringan }\end{array}$ & $\begin{array}{l}\text { Villa Pesona Asri Blok A18 } \\
\text { no.17 }\end{array}$ & 2014 & Perdagangan \\
\hline $\mathbf{4}$ & $\begin{array}{l}\text { Toko Fashion } \\
\text { Muslim }\end{array}$ & $\begin{array}{l}\text { Dc. Mall Lt. Dasar Blok } \\
\text { F26-27 }\end{array}$ & 2010 & Perdagangan \\
\hline $\mathbf{5}$ & $\begin{array}{l}\text { Toko Fathia } \\
\text { Collection }\end{array}$ & $\begin{array}{l}\text { Dc. Mall Lt. Dasar Blok GF } \\
\text { 69 }\end{array}$ & 2010 & Perdagangan \\
\hline
\end{tabular}

Sumber: Data Penelitian, 2020

Hasil penelitian dalam pengelolaan keuangan dengan menggunakan empat indikator yaitu penggunaan anggaran, pencatatan, pelaporan dan pengendalian menyesuaikan dengan hasil dari wawancara dan obeservasi yang telah dilakukan terhadap keuangan UMKM di kota Batam. Untuk hasil dari setiap wawancara yang dilakukan adalah sesuai dengan tabel berikut: 
Tabel 2. Hasil Penggunaan Anggaran

\begin{tabular}{lcccccc}
\hline \multirow{2}{*}{\begin{tabular}{l} 
Pernyataan \\
\cline { 2 - 7 }
\end{tabular}} & \multicolumn{2}{c}{ Mesponden } & \multicolumn{3}{c}{ Total Responden } \\
\cline { 2 - 7 } & Total & \% & Total & \% & Total & \% \\
\hline $\begin{array}{l}\text { Selalu membuat perencanaan } \\
\text { keuangan dalam usaha }\end{array}$ & 5 & 100 & - & - & 5 & 100 \\
\hline $\begin{array}{l}\text { Membuat perencanaan dalam } \\
\text { penjualan usaha }\end{array}$ & 5 & 100 & - & - & 5 & 100 \\
\hline $\begin{array}{l}\text { Kesulitan dalam membuat } \\
\text { perencanaan laba }\end{array}$ & 2 & 40 & 3 & 60 & 5 & 100 \\
\hline $\begin{array}{l}\text { Membandingkan perencanaan } \\
\text { yang dibuat dengan kenyataan }\end{array}$ & 2 & 40 & 3 & 60 & 5 & 100 \\
\hline $\begin{array}{l}\text { Melakukan evaluasi jika } \\
\text { terdapat selisih anggaran } \\
\text { aktual dengan kenyataan }\end{array}$ & 2 & 40 & 3 & 60 & 5 & 100 \\
\hline $\begin{array}{l}\text { Memisahkan uang pribadi } \\
\text { dengan uang modal }\end{array}$ & 1 & 20 & 4 & 80 & 5 & 100 \\
\hline $\begin{array}{l}\text { Memiliki cadangan kas untuk } \\
\text { pengeluaran tidak terduga }\end{array}$ & 1 & 20 & 4 & 80 & 5 & 100 \\
\hline $\begin{array}{l}\text { Membuat perencanaan } \\
\text { program masa depan }\end{array}$ & 5 & 100 & - & - & 5 & 100 \\
\hline
\end{tabular}

Sumber: Data Penelitian, 2020

Hasil indikator Penggunaan anggaran memiliki fungsi yang sangat banyak bagi UMKM, dan kelesuruhan dari UMKM atau 100\% memiliki perencanaan anggaran terhadap usaha yang dimiliki. Pelaku usaha mampu untuk dapat merencakanan anggaran yang harus dikeluarkan dan program masa yang akan datang. Pelaku usaha mampu membandingkan uang pribadi dan uang modal usaha, sehingga hal ini dapat dikatakan memiliki perencanaan anggaran yang baik. Namun dalam hasil penelitian pelaku usaha $80 \%$ tidak dapat membandingkan dan memisahkan usang pribadi dan usaha. Sehingga hal tersebut menjadi sebuah temuan bagi peneliti. Perencanaan penjualan dapat digunakan untuk memprediksi jumlah barang yang terjual, pendapatan yang akan diterima dan memperkirakan penjualan selanjutnya. Dengan adanya perencanaan anggaran maka tujuan usaha mereka untuk mendapatkan keuntungan akan tercapai. Pelaku usaha secara keseluruhan mengakui bahwa perencanaan masa depan harus dibuat akan tetapi secara khusus tidak diterapkan dengan baik. Perencanaan itu sendiri adalah bagaimana para pengelola menemukan cara terbaik dalam rangka mencapai tujuan perusahaan. Hasil penelitian serupa dengan (Puspitaningtyas, 2017) yang menyatakan bahwa UMKM cenderung melakukan pencatatan secara sederhana namun tidak lengkap seperti pencatatan kas masuk dan keluar.

Tabel 3. Hasil Pencatatan

\begin{tabular}{|c|c|c|c|c|c|c|}
\hline \multirow{3}{*}{ Pernyataan } & \multicolumn{2}{|c|}{ Responden } & \multicolumn{4}{|c|}{ Total Responden } \\
\hline & Mene & & Tidal & rapk & & \\
\hline & Total & $\%$ & Total & $\%$ & Total & $\%$ \\
\hline $\begin{array}{l}\text { Melakukan pencatatan } \\
\text { transaksi penjualan dan } \\
\text { pembelian }\end{array}$ & 5 & 100 & - & - & 5 & 100 \\
\hline $\begin{array}{l}\text { Pencatatan transaksi } \\
\text { penjualan dan pembelian } \\
\text { secara manual }\end{array}$ & 2 & 40 & 3 & 60 & 5 & 100 \\
\hline
\end{tabular}




\begin{tabular}{lcccccc}
\hline $\begin{array}{l}\text { Rutin melakukan transaksi } \\
\text { penjualan dan pembelian }\end{array}$ & 3 & 60 & 2 & 40 & 5 & 100 \\
\hline $\begin{array}{l}\text { Rutin melakukan rekapitulasi } \\
\text { kas setiap bulannya }\end{array}$ & 3 & 60 & 2 & 40 & 5 & 100 \\
\hline $\begin{array}{l}\text { Pencatatan transaksi } \\
\text { penjualan dan pembelian } \\
\begin{array}{l}\text { dapat membantu pengelolaan } \\
\text { keuangan }\end{array}\end{array}$ & 5 & 100 & - & - & 5 & 100 \\
\hline
\end{tabular}

Sumber: Data Penelitian, 2020

Hasil indikator Pencatatan penjualan yang dilakukan oleh UMKM masih menggunakan manual pada aktivitas pencatatan penjualan. Data menunjukkan bahwa pencatatan penjualan dilakukan seluruh UMKM. Keseluruhan dari UMKM yaitu dengan persentase $100 \%$ melakukan pencatatan penjualan setiap ada transaski penjualan yang terjadi. Penerapan pencatatan hanya sebatas pemsukan dan pengeluaran aja. Jadi untuk penerapan pencatatan secara garis besar belum dialkukan oleh semua UMKM. Kurangnya pemahaman dan pengetahuan pemilik usaha tentang membuat catatan rinci dari transaksi yang terjadi dalam usahanya. Dan adanya pelaku usaha yang menerapkan rekapitulasi hanya sebanyak 3 responden atau 60\%, sedangkan $40 \%$ tidak melakukan rekapitulasi dalam pencatatan penjualan. Hal ini menjadi penyebab kurangnya kesadaran untuk melakukan rekapitulasi terhadap pencatatan yang dilakukan. Hasil penelitian serupa dengan (Diyana, 2017) bahwa indikator pencatatan paling tinggi diterapkan oleh UMKM karena penjualan dianggap penting untuk mengetahui banyak terjadi penjualan setiap harinya.

Tabel 4. Hasil Pelaporan

\begin{tabular}{lcccccc}
\hline \multirow{2}{*}{ Pernyataan } & \multicolumn{2}{c}{ Responden } & \multicolumn{5}{c}{ Total Responden } \\
\cline { 2 - 7 } & \multicolumn{2}{c}{ Menerapkan } & \multicolumn{2}{c}{ Tidak Menerapkan } \\
\cline { 2 - 7 } & Total & \% & Total & \% & Total & \% \\
\hline $\begin{array}{l}\text { Membuat laporan keuangan } \\
\text { lengkap }\end{array}$ & - & - & 5 & 100 & 5 & 100 \\
\hline $\begin{array}{l}\text { Membuat laporan keuangan } \\
\text { neraca, laba rugi, dan arus } \\
\text { kas di awal bulan }\end{array}$ & - & - & 5 & 100 & 5 & 100 \\
\hline $\begin{array}{l}\text { Membuat laporan keuangan } \\
\text { untuk menilai kemajuan } \\
\text { usaha }\end{array}$ & 5 & 100 & - & - & 5 & 100 \\
\hline
\end{tabular}

Sumber: Data Penelitian, 2020

Kegunaan laporan yang dibuat adalah tidak hanya sekedar berisi angka-angka tetapi juga memiliki informasi yang dapat digunakan. Hal ini juga sesuai dengan hasil wawancara yang dilakukan bahwa UMKM tidak memberikan informasi yang relevan mengenai keuangan usaha. Hal ini dikarenakan pelaku usaha tidak memahami prosedur pembuatan laporan. Pelaporan yang dipahami hanyalah laporan yang diwajibkan untuk perusahaan jadi pendapat yang diberikan bahwa pelaporan untuk usaha sendiri tidak perlu dibuat. Kekurangannya adalah pengetahuan pemilik sangat terbatas dan hanya memahami secara logika dengan perhitungan pendapatan dikurangi biaya yang dikeluarkan saja. Jadi jika sudah mendapat keuntungan atau modal sudah kembali maka laporan tidak perlu dibuat lagi. Sehingga temuan dalam penelitian ini sebesar $100 \%$ dari pelaku usaha tidak melakukan pelaporan keuangan. Menurut (Mahayuni et al., 2017) tujuan utama pelaporan keuangan adalah memberikan informasi mengenai posisi keuangan, kinerja, dan arus kas suatu entitas yang berguna bagi sebagian besar pemakai untuk membuat dan mengevaluasi keputusan mengenai alokasi sumber daya yang dipakai suatu entitas dalam aktivitasnya guna mencapai tujuan. hasil penelitian serupa dengan (Dahlia Pinem dan \& M, 2019) yang menyatakan 
bahwa UMKM belum membuat laporan keuangan secara lengkap sesuai dengan Standar Akuntansi Keuangan yang berlaku. Hal ini dapat menyebabkan terjadinya kecurangan terhadap keuangan oleh pihak lain seperti pegawai/karyawan.

Tabel 5. Hasil Penegendalian

\begin{tabular}{|c|c|c|c|c|c|c|}
\hline \multirow{3}{*}{ Pernyataan } & \multicolumn{2}{|c|}{ Responden } & \multicolumn{4}{|c|}{ Total Responden } \\
\hline & Mene & & Tidal & erapk & & \\
\hline & Total & $\%$ & Total & $\%$ & Total & $\%$ \\
\hline $\begin{array}{l}\text { Memiliki proses penagihan } \\
\text { untuk penjualan secara } \\
\text { kredit }\end{array}$ & - & - & 5 & 100 & 5 & 100 \\
\hline $\begin{array}{l}\text { Memiliki prosedur atau } \\
\text { tahapan untuk penarikan } \\
\text { kas keluar }\end{array}$ & - & - & 5 & 100 & 5 & 100 \\
\hline $\begin{array}{l}\text { Membuat nota penjualan } \\
\text { untuk setiap } \\
\text { penjualan }\end{array}$ & 5 & 100 & - & - & 5 & 100 \\
\hline $\begin{array}{l}\text { Mengarsipkan } \\
\text { transaksi penjualan } \\
\text { pembelian }\end{array}$ & 5 & 100 & - & - & 5 & 100 \\
\hline
\end{tabular}

Sumber: Data Penelitian, 2020

Data yang diperoleh menunjukkan bahwa penerapan pengendalian pada pengelolaan keuagan UMKM tergolong baik. Hal ini dibuktikan dengan beberapa jawaban pelaku usaha untuk memberikan nota kepada pembeli, mengarsikan nota penjualan. Menyimpan bukti transaksi merupakan kegiatan UMKM yang dilakukan untuk pengendalian akan keuangan mereka. Namun kekurangan dari UMKM tidak semua pengendalian akan keuangan mereka lakukan. Pengendalian yang diterapkan hanya menggunakan nota dan penjualan tunai tidak menggunakan kredit. Bukti transaksi harus disimpan dengan tujuan untuk menjadi bukti pebukuan dilakukan sesuai dengan ketentuan pencatatan. Hasil penelitian serupa dengan (Octaviani et al., 2019) bahwa dalam kegiatan pengeluaran industri dilakukan menggunakan nota. Namun nota yang digunakan tidak seluruhkan digunakan hanya pembelian yang dilakukan dalam jumlah kecil saja.

\section{PEMBAHASAN}

Hasil wawancana yang telah dilaksanakan dapat dikatakan bahwa pengelolaan keuangan pada UMKM yang berada dikota Batam belum dapat dikatakan sempurna, dikarenakan setiap UMKM tidak secara keseluruhan menggunakan indikator yang ada pada pengelolaan keuangan. Indikator yang sering digunakan hanya perencanaan anggaran, pencatatan, serta pengendalian. Sedangkan pelaporan tidak digunakan karena banyaknya kendala yang dihadapi oleh UMKM. Pengelolaan keuangan adalah seluruh proses tersebut dilakukan untuk mendapatkan pendapatan perusahaan dengan meminimalkan biaya, selain itu dalam penggunaan dan pengalokasian dana yang efisien dapat memaksimalkan nilai perusahaan (Diyana, 2017).

Indikator yang diterapkan pada UMKM hanya bersifat umum seperti pencatatan dan pengendalian. Karena indikator ini dianggap lebih mudah untuk diterapkan dalam usaha kecil atau pun menengah. Pencatatan dan pengendalian yang sederhana memudahkan pelaku usaha untuk mengaplikasikan kedalam UMKM. Sehingga pelaku usaha tidak membutuhkan keahlian yang khusus dalam pembuatan laporan keuangan yang harus didasarkan pada Standar Akuntansi Keuangan yang berlaku. Sedangkan pada indikator perencanaan sudah digunakan oleh pelaku usaha ketika ingin membangun UMKM, sehingga sampai saat ini perencanaan masa depanpun masih tetap diterapkan agar dapat melihat perkembangan usaha.

Hasil wawancara pada 5 UMKM secara keseluruhan menunjukkan bahwa Toko Pakaian Cantik, Toko Gamis Taqeeya, Toko Makanan Ringan, Toko Fashion Muslim, dan Toko Fathia Collection tidak keseluruhan menggunakan pengelolaan keuangan. 
Toko Pakaian Cantik merupaan UMKM yang bergerak pada bidang pakaian wanita dan pria yang berdiri sejak tahun 2014, pelaku usaha memiliki usaha dari modal sendiri dan tidak memiliki karyawan pada usahanya. Kedala dalam Toko Pakaian Cantik dalam mengelola keuangan adalah tidak dapat memisahkan keuangan pribadi dan keuangan usaha dikarenakan menggunakan modal sendiri. Serta tidak memiliki keahlian dalam membuat laporan keuangan dan tidak sanggup untuk menggaji karyawan untuk keahlian dalam akuntansi. Sehingga peneliti memberikan solusi dengan menggunakan aplikasi yang dapat menunjang dalam pencatatan serta dapat mengontrol keuangan usaha setiap bulannya.

Kemudian toko Gamis Taqeeya merupakan UMKM yang bergerak dibidang pakaian gamis wanita yang berdiri sejak tahun 2011, pelaku usaha memiliki usaha dari modal sendiri dan dibangun dalam kompleks perumahan pribadi. Kendala yang dihadapi oleh pelaku usaha adalah tidak memiliki keahlian yang memadai dalam menggunakan pengelolaan keuangan, tidak merasa penting dalam melakkan pelaporan keuangan dan kurangnya pengendalian yang digunakan. Sehingga dalam hal ini peneliti memberikan pengetahun mengenai akuntansi dan bagaimana cara membuat laporan keaungan secara sederhana agar dapat diterapkan dalam usaha.

Toko Makanan Ringan merupakan UMKM yang bergerak dibidang berbagai jenis makanan yang berdiri sejak tahun 2014, pelaku usaha memiliki usaha dari usaha di rumah pribadi. Kendala yang dihadapi oleh pelaku usaha adalah hanya kurangnya kemampuan dalam laporan keuangan, sedangkan pengendalian dan pencatatan dilakukan dengan baik. Sehingga dalam hal ini peneliti hanya memberikan pengetahuan dalam hal penyusunan laporan keuangan secara sederhana agar dapat diterapkan dalam usaha.

Selanjutnya toko fashion muslim merupakan UMKM yang bergerak dalam bidang pakaian pria dan wanita muslim yang berdiri pada tahun 2010. Kendala yang dihadapi dalam usaha adalah kurangnya pengendalian dan tidak menggunakan laporan keuangan dalam usahanya. Sehingga peneliti menyarankan untuk menambah pengendalian agar dapat melakukan pencatatan dalam keuangan menggunakan pengendalian dan memberikan pengetahuan dalam membuat laporan keuangan yang sederhana dalam usaha.

Terakhir adalah toko fathia collection yang merupakan UMKM yang berdiri pada tahun 2010 dan bergerak dibidang pakaian muslim, hijab dan sajadah. Pelaku usaha membangun usaha dengan modal sendiri dan memiliki kendala dalam membuat laporan keuangan. Keahlian dalam membuat keuangan sangat spesifik dan harus memahami secara mendalam agar dapat diterapkan pada usaha. Sehingga peneliti memberikan pengetahuan kepada pelaku usaha dalam membuat laporan keuangan secara sederhana dan dapat diterapkan dalam usaha.

\section{KESIMPULAN}

Berdasarkan hasil wawancara, penelitian ini memiliki kesimpulan sebagai berikut: (a) Pengelolaan kuangan pada UMKM di Batam Kota masih sangat sederhana, secara keseluruhan hanya menggunakan anggaran, pencatatan dan pengendalian yang sederhana, dan tidak melakukan pelaporan atas keuangan usaha sehingga pelaku usaha harus belajar dan memahami mengenai pengelolaan kuangan agar dapat menilai kesehatan usaha. (b) Rendahnya pemahaman dan pengetahuan UMKM tentang mengelola keuangan usaha sehingga pelaku usaha harus meningkatkan kinerja agar dapat bersaing. (c) Untuk Dinas Koperasi terkait harus mengadakan pelatihan dan pembinaan terhadap UMK di Kota Batam agar UMKM dapat berkembang dan bersaing.

Keterbatasan dalam penelitian ini adalah banyak dari UMKM yang tidak aktif, berpindah lokasi baru, atau sulitnya menemukan pelaku usaha untuk dapat diwawancara. Hal ini disebabkan adanya tidak terbukanya pelaku usaha dalam informasi yang diberikan mengenai pengelolaan keuangan yang digunakan dalam usaha. Informasi menenai keuangan usaha memang sangat sensitif dan hal ini yang menyebabkan peneliti kesulitan dalam mendapatkan informasi yang detail. Informasi yang diterima hanya sebatas kemampuan pelaku/informan dalam memberikan informasi yang dapat digunakan sebagai informasi yang sederhana. 
Batam, D. U. (2019). Data USAHA MIKRO CETAK.

\section{REFERENSI}

Dahlian Pinem dan, \& M, B. D. (2019). Pengelolaan Manajemen Usaha Konveksi Pada Umkm Di Depok. 127-132.

Davayudhanti, A., Darmansyah, A., \& Sutardi, A. (2019). The Determinant Factors of Micro , Small, and Medium Enterprises Towards Financing Source Decision. 5(1), 611-621.

Depkop. (2018). Perkembangan Data Usaha Mikro , Kecil , Menengah Dan Usaha Besar. Www.Depkop.Go.Id, 2000(1), 1.

Diyana. (2017). Analisis Pengelolaan Keuangan Usaha Mikro Kecil dan Menengah Studi Kasus Pada Asosiasi Batik Mukti Manunggal Kabupaten Sleman. Universitas Sanata Dharma, 4, 9 15.

Fatwitawati, R. (2018). Pengelolaan Keuangan Bagi Usaha Mikro Kecil Menengah (UMKM) Di Kelurahan Airputih Kecamatan Tampan Kota Pekanbaru. Sembadha, 32.

Kostini, N., \& Raharja, S. J. (2020). Analysis of Financial Behavior of SMEs in the Creative Industries in Bandung City, Indonesia. Review of Integrative Business and Economics Research, 9(1), 131-139. https://search.proquest.com/docview/2220699211 ?accountid=17242\%0Ahttp://buscompress .com/riber-9-1.html

Mahayuni, N. P. S., Yuniarta, G. A., \& Julianto, I. P. (2017). e-Journal S1 Ak Universitas Pendidikan Ganesha. Akuntansi, 8(2), 4.

Noer Sasongko 1), R. T. (2019). No Title. Seminar Nasional \& Call For Paper Seminar Bisnis Magister Manajemen (SAMBIS-2019), 287-291.

Octaviani, S. D., Dianita, E., Dewi, M., Kurniawan, P. S., \& Ekonomi, J. (2019). ANALISIS PENGELOLAAN KEUANGAN UMKM DALAM UPAYA PEMBINAAN KEMANDIRIAN WARGA BINAAN PEMASYARAKATAN ( WBP ) RUMAH TAHANAN KELAS II B NEGARA ( Studi Kasus Pada Rumah Tahanan Kelas IIB Negara).

Puspitaningtyas, Z. (2017). Pembudayaan Pengelolaan Keuangan Berbsis Akuntansi bagi Pelaku UKM. Jurnal Akuntansi, XXI(03), 361-372.

Ria, A. (2018). Analisis Penerapan Aplikasi Keuangan Berbasis Android. 10(3), 207-219.

Risnaningsih, R. (2017). Pengelolaan Keuangan Usaha Mikro Dengan Economic Entity Concept. Jurnal Analisa Akuntansi Dan Perpajakan, 1(1), 41-50. https://doi.org/10.25139/jaap.v1i1.97

Sabiq Hilal Al Falih, M., Rizqi, R. M., \& Adhitya Ananda, N. (2019). Pengelolaan Keuangan Dan Pengembangan Usaha Pada Usaha Mikro Kecil Menengah (Studi Kasus Pada Umkm Madu Hutan Lestari Sumbawa). Jurnal Manajemen Dan Bisnis, 2(1). https://doi.org/10.37673/jmb.v2i1.302

Suindari, N. M., \& Juniariani, N. M. R. (2020). Pengelolaan Keuangan, Kompetensi Sumber Daya Manusia Dan Strategi Pemasaran Dalam Mengukur Kinerja Usaha Mikro Kecil Menengah (Umkm). KRISNA: Kumpulan Riset Akuntansi, 11(2), 148-154. https://doi.org/10.22225/kr.11.2.1423.148-154

Sujarweni, v. W. (2020). Metodoligi Penelitian. PUSTAKAB ARUPRESS.

Tanan, C. I., \& Dhamayanti, D. (2020). Pendampingan UMKM dalam Pengelolaan Keuangan Usaha Guna Peningkatan Ekonomi Masyarakat di Distrik Abepura Jayapura. 1(2), 173-184. https://doi.org/10.37680/amalee.v1i2.408 